\title{
Breed and maturity effects on Churra Galega Bragançana and Suffolk lamb carcass characteristics: Killing-out proportion and composition
}

\author{
S. Rodrigues *, V. Cadavez, A. Teixeira \\ Escola Superior Agrária, Instituto Politécnico de Bragança, Apt. 1172, 5301-855, Bragança, Portugal
}

Received 26 April 2005; received in revised form 27 July 2005; accepted 27 July 2005

\begin{abstract}
The aim of this work was to study the carcass killing-out proportions and carcass composition of Churra Galega Bragançana (CGB) and Suffolk sheep at 20\%, 25\%, 30\% and 35\% of maturity. Forty-eight male lambs were used, 24 CGB and 24 Suffolks from the Bragana's School of Agriculture sheep flock. Suffolk lambs had greater proportions of leg, shoulder and breast joints, but lower proportions of rib, anterior rib and neck joints. Increasing maturity caused a significant decrease in leg and shoulder proportions and an increase in chump proportion. Suffolk lambs had significantly greater muscle and significantly less subcutaneous fat and kidney and pelvic fat percentages than CGB lambs. With the increase of maturity, a significant increase in intermuscular fat and a significant decrease in bone proportion were observed. It was concluded that, under the management conditions of this work, Suffolks were preferred for meat production, since at a comparable stage of maturity they had greater proportions of expensive cuts and greater carcass lean percentage.
\end{abstract}

(c) 2005 Elsevier Ltd. All rights reserved.

Keywords: Lambs; Killing-out; Carcass composition

\section{Introduction}

Colomer-Rocher (1973) defined carcass quality as that group of, weighted, carcass characteristics that correlated closely with maximum consumer acceptance. However, carcass quality could be closely related to its market value and producers, butchers and consumers have different, and sometimes contradictory, carcass quality parameters. In fact, Boccard and Dumont (1976) presented the quality concepts of: (1) producers, to whom a quality carcass is the one from a fast growth animal, that assures a good income and high profit; (2) butchers, who consider a quality carcass the one that gives the higher proportion of valued joint and (3) consumers, that related carcass quality with visual aspects, like joint shape, tissue composition (meat and fat) and of organoleptic factors (odour, taste, juiciness

\footnotetext{
* Corresponding author. Tel.: +351 273303 221; fax: +351 273325405 . E-mail address: srodrigues@ipb.pt (S. Rodrigues).
}

and tenderness). Lamb carcass quality corresponds to a complex set of characteristics, some of which are subjective and difficult to evaluate. We can justify the great amount of published work if we want to provide uniformity and objectivity to evaluation systems in most countries. To properly guide improvements in production, it is necessary to know in detail the quality traits of local as well as exotic breeds.

The commercial value of meat animals is determined by the carcass weight, proportion and distribution of carcass muscle, fat and bone, and the proportion of expensive cuts.

Nowadays more and more importance is given to meat quality. Information about carcass quality is an important factor in determining meat quality.

Traditionally, lambs produced in the Mediterranean countries of the EU are slaughtered at a very young age (between 1 and 4 months), producing the lightest carcasses in all Europe, Teixeira, Delfa, and Alberti (1998). One of the most important breeds in northeast of Portugal is the Churra Galega Bragançana breed with a flock of 9000 
sheep (number of registered animals in 2000). This breed is of high economic importance to the region, as it is perfectly adapted. From this breed is produced a product with origin denomination protection, the "Borrego Bragançano" which is a carcass of the CGB lambs raised under the traditional production system, slaughtered between 3 and 4 months of age resulting in a carcass weight range between 8 and $12 \mathrm{~kg}$.

The use of specialised meat breeds to improve animal productivity and economic results is desirable in some intensive sheep production conditions. The trend for heavier and leaner carcasses is widespread and favoured by the use of a large mature weight breed such as Suffolk (Wood, MacFie, Pomeroy, \& Twinn, 1980). The British Suffolk is a meat breed which is widely used in terminal crossbred systems (Kempster, Croston, Guy, \& Jones, 1987), producing good results in crosses with local breeds, producing heavy carcasses, with low fat content and fast growth (Teixeira, Delfa, \& Treacher, 1996). Suffolk, together with the Merino Precoce and Ile de France, are the most important breeds used for crossbreeding in Portugal. The Suffolk breed was introduced to the north-east of Portugal in 1984, when two males and one female were presented by the United Kingdom ambassador to the Polytechnic Institute of Bragança. Two years later a further 15 females and 10 males were imported from the Suffolk Sheep Society in the United Kingdom.

In spite of several studies on carcass quality, there is no satisfactory information on the characterization of most Portuguese lamb. It is important to know the quantitative and qualitative characteristics of these lamb products, to provide suitable information to producers and consumers. Therefore, an experiment was conducted to compare the killing-out proportions and carcass composition of CGB with Suffolk breeds at $20 \%, 25 \%, 30 \%$ and $35 \%$ of maturity.

\section{Materials and methods}

Lambs were raised under natural conditions of Bragana's School of Agriculture farm, located in the north-east of Portugal, at above $500 \mathrm{~m}$. The farm has intensive management, producing lambs off grass, conserved forages and finished on commercial concentrates. The weather is characterized by long and cold winters and very hot summers.

Forty-eight intact male lambs were used, 24 of CGB local breed and 24 of Suffolk breed randomly selected from the experimental flock at the Bragança's School of Agriculture (Escola Superior Agrária de Bragança). Live weight was periodically recorded, in order to slaughter lambs at weights corresponding to $20 \%, 25 \%, 30 \%$ and $35 \%$ of maturity.

Prud'Hon (1976) referred the possibility of defining sheep "degree of maturity" as: (Slaughter weight/Adult weight $) \times 100$. This parameter cannot be exactly known; however, errors are small, if we consider as "adult live weight" the average live weight of adult animals of the same breed and sex. The adult live weight for each breed was estimated as the live weight average of adult males belonging to the same flock. The estimated live weight values were $66.7 \mathrm{~kg}$ for CGB breed and $95.6 \mathrm{~kg}$ for Suffolk breed.

After $24 \mathrm{~h}$ of fasting, lambs were slaughtered, over a 2year period, in the experimental slaughterhouse of the Bragança's School of Agriculture. All lambs were slaughtered under the same conditions and in accordance with the laws of ethics and welfare of the animals. After slaughter, gut contents were removed, weighed, and subtracted from the live weight in order to obtain empty body weight. Kidney and pelvic fat (KKCF - perinephric and retroperitoneal fat) were removed and weighed separately. Immediately after slaughter the hot carcass weight $(\mathrm{HCW})$ was obtained. Carcasses were cooled at $4{ }^{\circ} \mathrm{C}$, in a vertical refrigerator chamber, for 24 hours so as to obtain the cold carcass weight $(\mathrm{CCW})$.

Carcasses were halved through the vertebral column and the left side was divided into eight standardized commercial joints: leg, chump, loin, ribs, anterior ribs, shoulder, breast and neck, according to the jointing procedure system of the Zootechnical National Station cut (Estação Zootécnica Nacional - EZN cut), as outlined by Calheiros and Neves (1968). This jointing procedure considers leg, chump, and loin as 1st category joints; ribs, anterior ribs and shoulder as 2nd category joints and breast and neck as 3rd category joints. Each joint was then dissected into muscle, subcutaneous fat, intermuscular fat, bone, and remainder (major blood vessels, ligaments, tendons and thick connective tissue sheets associated with some muscles) in a dissection room under controlled environment.

Data were analysed using the Mixed Models Procedure (Proc Mixed) of SAS (1998), using Breed and Degree of Maturity as fixed effects and their interaction. A Tukey's pairwise test was used to examine the significance of the differences between breed and maturity least-square means.

\section{Results}

\subsection{General data}

Mean, standard deviation and coefficient of variation for live weight, empty live weight, hot and cold carcass weight and left half carcass weight of CGB and Suffolk lambs by degree of maturity, are shown in Table 1. As expected, when compared at the same degree of maturity, Suffolk lambs had the highest live weights. The coefficients of variation of the variables studied of the CGB groups degree of maturity were lower than the coefficients for the Suffolk groups. Within the Suffolk groups the higher degrees of maturity had more homogeneous coefficients of variation.

\subsection{Killing-out proportion}

Least-square means of breed and degree of maturity effects on killing-out proportions are shown in Table 2. When killing-out proportion was corrected by removing the variation caused by the gut contents, the differences between breeds were reduced. However, CGB lambs showed 
Table 1

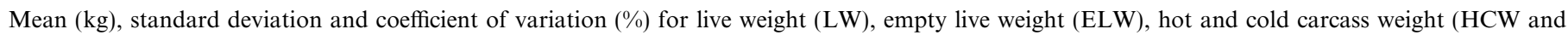
CCW) and left half carcass weight (LHCW) of Churra Galega Bragançana and Suffolk lambs by degree of maturity

\begin{tabular}{|c|c|c|c|c|c|c|c|c|}
\hline \multirow[t]{3}{*}{ Breed } & \multicolumn{8}{|c|}{ Degree of maturity } \\
\hline & \multicolumn{2}{|l|}{$20 \%$} & \multicolumn{2}{|l|}{$25 \%$} & \multicolumn{2}{|l|}{$30 \%$} & \multicolumn{2}{|l|}{$35 \%$} \\
\hline & $\mathrm{M} \pm \mathrm{SD}$ & $\mathrm{CV}$ & $\mathrm{M} \pm \mathrm{SD}$ & $\mathrm{CV}$ & $\mathrm{M} \pm \mathrm{SD}$ & $\mathrm{CV}$ & $\mathrm{M} \pm \mathrm{SD}$ & $\mathrm{CV}$ \\
\hline \multicolumn{9}{|l|}{$C G B$} \\
\hline LW & $13.4 \pm 1.0$ & 7.5 & $16.7 \pm 0.6$ & 3.4 & $20.1 \pm 0.5$ & 2.3 & $23.3 \pm 0.4$ & 1.7 \\
\hline ELW & $11.9 \pm 0.8$ & 6.6 & $14.4 \pm 0.3$ & 2.4 & $17.8 \pm 0.3$ & 1.7 & $20.5 \pm 0.7$ & 3.5 \\
\hline $\mathrm{HCW}$ & $7.0 \pm 0.7$ & 9.8 & $8.4 \pm 0.4$ & 4.2 & $10.4 \pm 0.4$ & 4.1 & $11.9 \pm 0.6$ & 4.7 \\
\hline $\mathrm{CCW}$ & $6.9 \pm 0.7$ & 10.1 & $8.2 \pm 0.4$ & 4.6 & $10.2 \pm 0.4$ & 4.0 & $11.5 \pm 0.6$ & 4.8 \\
\hline \multicolumn{9}{|l|}{ Suffolk } \\
\hline LW & $19.6 \pm 1.9$ & 9.6 & $24.3 \pm 2.0$ & 8.1 & $28.8 \pm 1.0$ & 3.4 & $33.2 \pm 2.1$ & 6.3 \\
\hline ELW & $16.4 \pm 1.9$ & 11.7 & $20.8 \pm 2.1$ & 10.2 & $23.0 \pm 0.8$ & 3.5 & $27.7 \pm 2.0$ & 7.2 \\
\hline $\mathrm{HCW}$ & $9.1 \pm 1.1$ & 12.4 & $11.9 \pm 1.3$ & 10.9 & $13.5 \pm 0.5$ & 3.8 & $16.1 \pm 1.5$ & 9.3 \\
\hline $\mathrm{CCW}$ & $8.9 \pm 1.2$ & 13.0 & $11.6 \pm 1.30$ & 11.2 & $13.2 \pm 0.5$ & 3.8 & $15.8 \pm 1.5$ & 9.4 \\
\hline
\end{tabular}

higher $(P<0.001)$ hot and cold killing-out proportions, and higher $(P<0.05)$ corrected hot killing-out proportion. Although not significant, Suffolk lambs had higher corrected cold killing-out proportion. Our results seems to confirm the theory that meat breeds tend to have smaller killing-out proportions than dam breeds (Hammell \& Laforest, 2000; Wood, MacFie, \& Brown, 1983; Wylie, Chestnutt, \& Kilpatrick, 1997), since CGB breed presents dam breed characteristics (Teixeira et al., 1996). The degree of maturity had no effect $(P>0.05)$ on killing-out proportions. Nevertheless, Kremer et al. (2004) found significant differences with lambs of weight ranges similar to that used in this work, which can be due to breed or stage of maturity differences.

Table 2

Least-square means by breed and degree of maturity for killing-out proportion

\begin{tabular}{lcccc}
\hline & HKP & CKP & CHKP & CCKP \\
\hline Breed & & & & \\
CGB & $51.4^{\mathrm{a}}$ & $50.2^{\mathrm{a}}$ & $58.5^{\mathrm{a}}$ & 57.1 \\
Suffolk & $47.7^{\mathrm{b}}$ & $46.6^{\mathrm{b}}$ & $57.3^{\mathrm{b}}$ & 56.0 \\
SE & 0.52 & 0.54 & 0.38 & 0.41 \\
Degree of maturity & & & & \\
20 & 49.5 & 48.4 & 57.2 & 55.8 \\
25 & 49.5 & 48.5 & 57.8 & 56.5 \\
30 & 49.3 & 48.2 & 58.6 & 57.3 \\
35 & 49.8 & 48.6 & 58.0 & 56.6 \\
SE & 0.73 & 0.76 & 0.54 & 0.58 \\
Principal effects & & & & \\
Breed & $* * *$ & $* * *$ & $*$ & n.s. \\
Maturity & n.s. & n.s. & n.s. & n.s. \\
Interaction B $\times \mathrm{M}$ & n.s. & n.s. & n.s. & $*$ \\
\hline
\end{tabular}

HKP - hot killing-out proportion, CKP - cold killing-out proportion, CHKP - corrected hot killing-out proportion, CCKP - corrected cold killing-out proportion.

$\mathrm{a}, \mathrm{b}$ - means with the same superscript within the same column did not differ significantly $(P>0,05)$. SE - standard error.

n.s. - not significant.

${ }^{*} P<0.05$.

*** $P<0.001$.
No differences were found between breeds for corrected cold killing-out proportion. Nevertheless, the differences for killing-out proportion found between CGB and Suffolk, could be explained by the differences in abdominal fat deposition, as previously observed by Wood et al. (1980) and by Teixeira et al. (1996), these last authors had worked with the same breeds used in this study.

\subsection{Carcass composition}

Least-square means by breed and degree of maturity, for the percentages of commercial joints are shown in Table 3 . Suffolk lambs had higher $(P<0.01)$ leg, shoulder and breast percentages and lower $(P<0.001)$ percentage of ribs, anterior ribs, and neck than CGB lambs. No differences $(P>0.05)$ were found between breeds for loin and chump percentages. Kirton et al. (1996), in a study with 15 different breeds, also found a higher percentage of leg in Suffolk lambs. These results seem to confirm the superiority of Suffolk breed to develop higher proportions of expensive joints.

Decreases in leg $(P<0.01)$ and shoulder $(P<0.001)$ and an increase $(P<0.01)$ in chump percentages were observed with increasing maturity. There was no interaction between breed and maturity effects. These results confirmed that as the animal grows the percentage of some of the most valuable joints increases (Hammond Jr., Mason, \& Robinson, 1971). Alternatively, Jeremiah, Jones, Tong, Robertson, and Gibson (1997a) indicated that animals should be slaughtered at young ages and low weights in order to obtain a higher proportion of the most valuable joints, what is in accordance with Santos-Silva, Mendes, and Bessa (2002) who observed a significant decreasing effect of slaughter weight on higher value joint percentages for Merino Branco and Ile de France $\times$ Merino Branco lambs, and contradicts our results, even though different breeds were used in this work. However, the cost per $\mathrm{kg}$ of meat could be reduced if we spread the slaughtering cost over more $\mathrm{kg}$ of carcass, and allow animals to grow to heavier weights without compromising quality. 
Table 3

Least square means by breed and degree of maturity for the carcass joints percentage

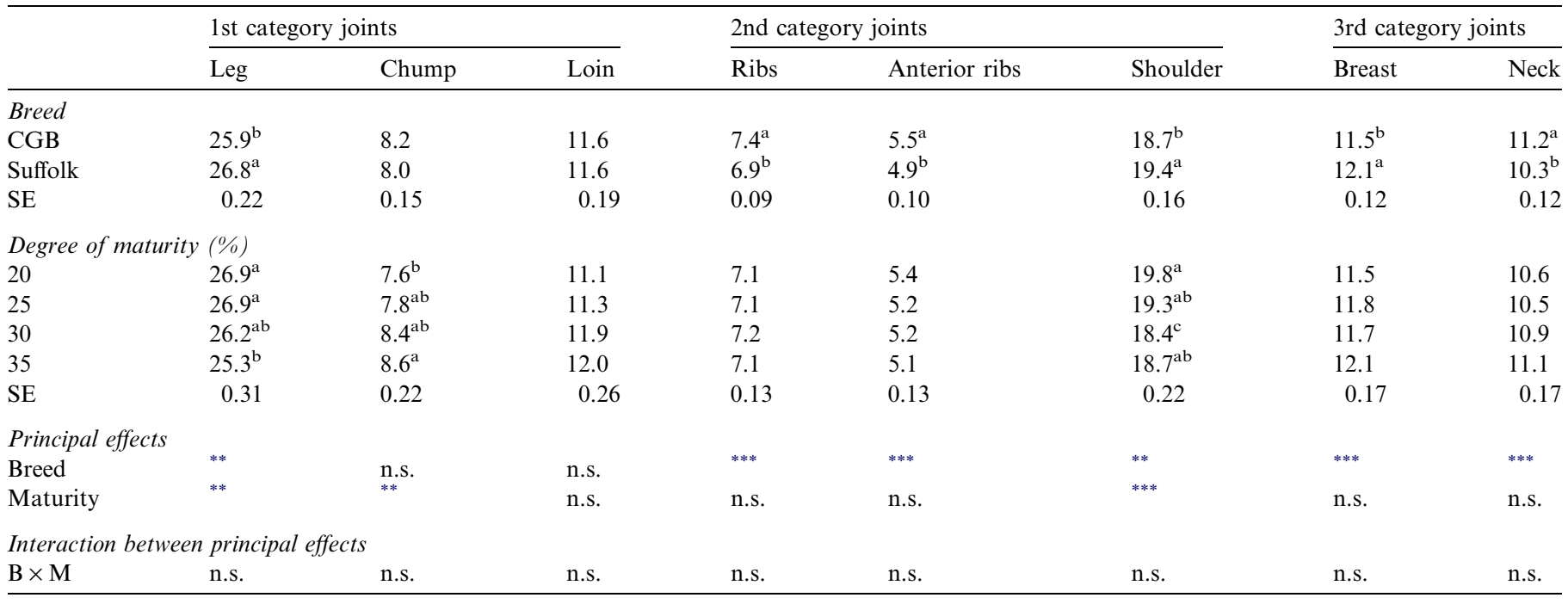

a-c - means with the same superscript within the same column did not differ significantly $(P>0.05)$. SE - standard error.

n.s. - not significant.

** $P<0.01$.

*** $P<0.001$.

The significant decrease in leg proportion was also observed by Kremer et al. (2004), as the carcass weight increased from a minimum of 8 to a maximum of $23.5 \mathrm{~kg}$ in Corriedale lambs.

Carcass tissue proportions of the CGB and Suffolk lambs are shown in Table 4. Suffolk lambs had a greater $(P<0.001)$ muscle proportion and a lower subcutaneous fat proportion $(P<0.01)$ and $\mathrm{KKCF}$ proportion $(P<0.001)$ than CGB lambs. Teixeira et al. (1996) verified that CGB breed and its crosses with Suffolk or Merino breeds did not differ in carcass muscle proportion, when slaughter weight varied between 20 and $40 \mathrm{~kg}$. Nevertheless, the highest muscle proportion of Suffolk lambs confirms Suffolk as a meat breed, as observed by Wolf, Smith, and Sales (1980) Croston, Kempster, Guy, and Jones (1987).

Teixeira et al. (1996) found that CGB lambs had a significantly smaller bone percentage than Suffolk or Merino cross lambs. These results are contradictory to those presented in this paper and could be explained by the different experimental conditions used.

Regarding fat percentage, the results obtained in the present work are not in total agreement with Crouse, Bus-

Table 4

Least-square means for carcass tissues percentage of Churra Galega Bragançana and Suffolk lambs

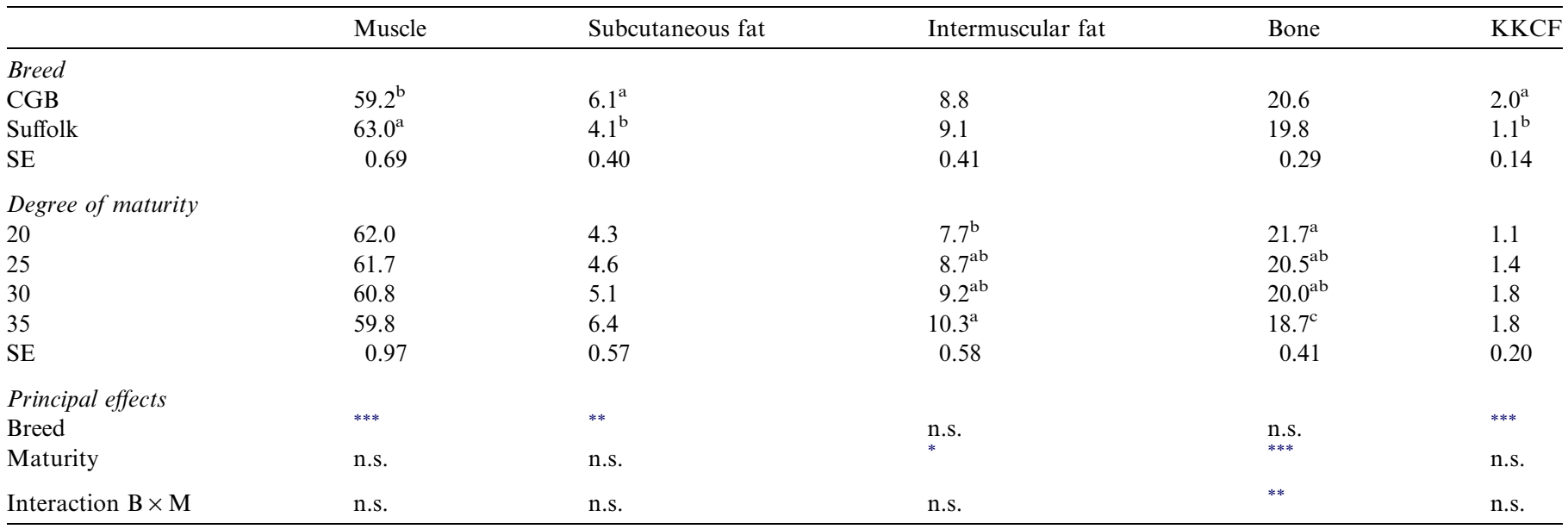

KKCF - kidney and pelvic fat.

$\mathrm{a}-\mathrm{c}-$ means with the same superscript within the same column did not differ significantly $(P>0.05)$. SE - standard error.

n.s. - not significant.

${ }^{*} P<0.05$.

${ }^{* *} P<0.01$.

*** $P<0.001$. 
boom, Field, and Ferrell (1981), as they concluded that breed does not influence the deposition of extremal fat. However, the cited authors found that breed had an effect on kidney and pelvic fat deposition in agreement with our results. But Kirton, Bennett, Dobbie, Mercer, and Duganzich (1995) and Kirton, Carter, et al. (1995) registered significant differences between breeds in studies involving about 15 different breeds. According to our results, Teixeira et al. (1996) found differences between CGB, Suffolk and Merino breeds for subcutaneous fat and KKCF percentages, however no significant differences were found for the intermuscular and total fat percentages.

An increase $(P<0.05)$ in intermuscular fat and a decrease $(P<0.001)$ in bone percentage were observed with increasing maturity. These results are in accordance with those of Butterfield, Griffiths, Thompson, Zamora, and James (1983) Butterfield, Zamora, Thompson, Reddacliff, and Griffiths (1984). The muscle percentage remained relatively constant with increasing maturity; in accordance with the theory proposed by Jury, Fourie, and Kirton (1977), and confirmed by Butler-Hogg and Whelehan (1987), which showed that the muscle weight distribution is established immediately after birth, and changes little thereafter. Contrarily, Jeremiah, Jones, Tong, Robertson, and Gibson (1997b), in a study with 10 breeds, observed a decrease in muscle percentage with increasing slaughter weight concluding that lambs should be marketed at low live weights in order to produce lean lambs. Similar results were found by Santos-Silva et al. (2002), working with the Portuguese Merino breed.

\subsection{Tissue ratios}

Least-square means for the breeds and degree of maturity for the carcass tissue ratios are shown in Table 5 . Lambs of CGB breed presented lower muscle/bone $(P<0.001)$ and muscle/dissectible fat $(P<0.05)$ ratios and a higher subcutaneous fat/dissectible fat $(P<0.001)$ ratio than Suffolk lambs. The advantage of Suffolk breed reflected in a higher muscle/fat ratio was also evident in the results obtained by Wolf et al. (1980) and Croston et al. (1987). On the other hand, Teixeira et al. (1996), in a study with the CGB breed with Suffolk $\times$ CGB and Merino $\times$ CGB crossbreds, found small differences in carcass composition and tissue ratios. These results seem to confirm the Suffolk breed, is a specialized meat breed, with high muscularity and a low tendency for fat deposition.

The muscle/bone ratio increased $(P<0,01)$ with increase in the degree of maturity. Similar results were found by Fourie, Kirton, and Jury (1970) and Broad and Davies (1981). A significant decrease of the muscle/dissectible fat ratio and an increase of the subcutaneous fat/dissectible fat ratio were found with increasing degree of maturity. Accordingly Kremer et al. (2004) reported that, in Corriedale lambs, as carcass weight increased from a minimum of $8 \mathrm{~kg}$ to a maximum of $23.5 \mathrm{~kg}$, saleable meat yield/bone
Table 5

Least-square means by breed and degree of maturity for the relationships between the carcass tissues

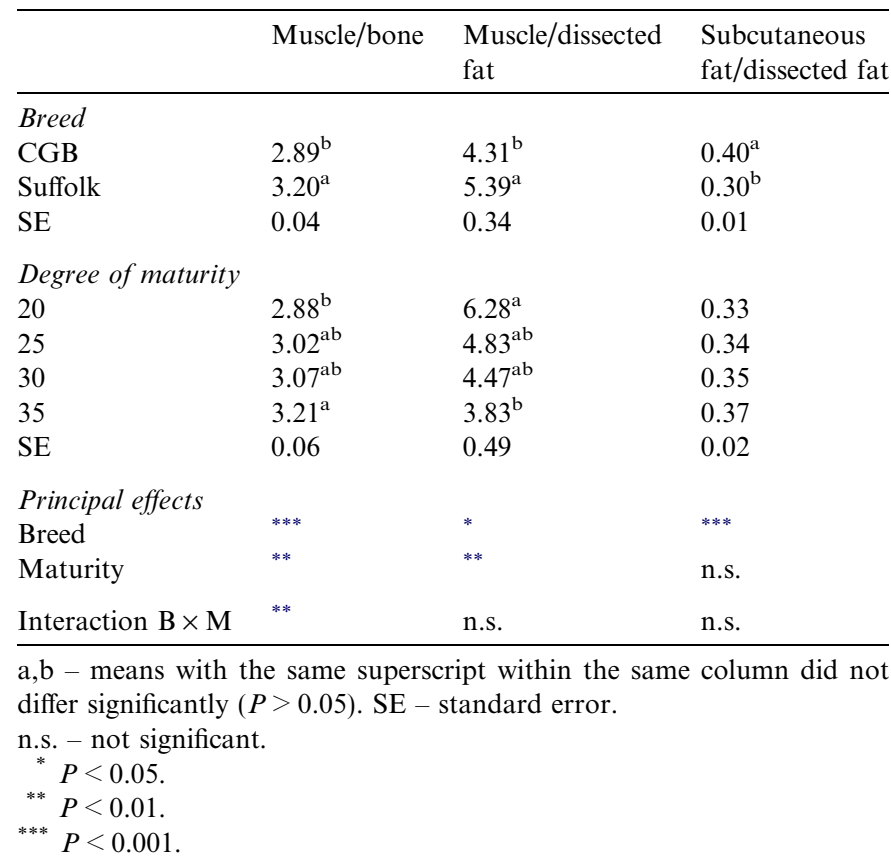

ratio increased and saleable meat yield/subcutaneous fat ratio decreased.

\section{Conclusion}

The results indicate that for the same degree of maturity CGB lambs showed higher killing-out proportions. Suffolk lambs produced more lean meat and CGB lambs had the greater carcass fat percentage. Subcutaneous fat has an important role in carcass protection during the cooling process. On the other hand, the Portuguese consumer seeks carcasses with a minimum of fat. In this way, a content of subcutaneous fat from $6 \%$ to $11 \%$ is considered to provide an appropriate protection to the carcass during cooling and also have good acceptance with consumers. The optimum slaughter point for CGB lambs could be located between the $30 \%$ and the $35 \%$ of maturity. For that maturity degree, lambs should be slaughtered between about 20 and $23 \mathrm{~kg}$ of live weight, corresponding to 10 and $12 \mathrm{~kg}$, carcasses, respectively. Suffolk lambs can be slaughtered above the $35 \%$ of maturity if they have values of subcutaneous fat less than $6 \%$. Taking into account the limitations imposed by the production System, Suffolk could bring some production advantages, once it can be slaughtered at higher weights, with larger muscle production, contributing to a larger profitability through a larger amount of final product: the meat.

\section{References}

Boccard, R., \& Dumont, B. L. (1976). La qualite des carcasses ovines In: 2émes Journees de la Recherche Ovine et Caprine, Paris. ITOVIC. 1-2 December 1976. pp. 44-78. 
Broad, T. E., \& Davies, A. S. (1981). Pre- and postnatal study of the carcass growth of sheep 3. Growth of dissectable and chemical components of muscle, and changes in the muscle:bone ratio. Animal Production, 32, 235-243.

Butler-Hogg, B. W., \& Whelehan, O. P. (1987). Muscle growth and distribution of muscle weight in Clun and Southdown sheep. Animal Production, 44, 133-142.

Butterfield, R. M., Griffiths, D. A., Thompson, J. M., Zamora, J., \& James, A. M. (1983). Changes in body composition relative to weight and maturity in large and small strains of Australian Merino rams 1. Muscle, bone and fat. Animal Production, 36, 29-37.

Butterfield, R. M., Zamora, J., Thompson, J. M., Reddacliff, K. J., \& Griffiths, D. A. (1984). Changes in body composition relative to weight and maturity of Australian Dorset Horn rams and wethers. 1. Carcass muscle, fat and bone and body organs. Animal Production, 39, 251-258.

Calheiros, F., \& Neves, A. (1968). Rendimentos ponderais no borrego Merino Precoce. Carcaça e $5^{\circ}$ Quarto.. Sep Boletim Pecuário, 117-126.

Colomer-Rocher, F. (1973). Exigências de calidad en la canai. An INIA/ Ser Prod Animal, 4, 117-132.

Croston, D., Kempster, A. J., Guy, D. R., \& Jones, D. W. (1987). Carcass composition of crossbred lambs by ten sire breeds compared at the same carcass subcutaneous fat proportion. Animal Production, 44, 99-106.

Crouse, J. D., Busboom, J. R., Field, R. A., \& Ferrell, C. L. (1981). The effects of breed, diet, sex, location and slaughter weight on lamb growth, carcass composition and meat flavor. Journal of Animal Science, 53, 376-386.

Fourie, P. D., Kirton, A. H., \& Jury, K. E. (1970). Growth and development of sheep II. Effect of breed and sex on the growth and carcass composition of the Southdown and Romney and their cross. New Zealand Journal of Agricultural Research, 13, 753-770.

Hammell, K. L., \& Laforest, J. P. (2000). Evaluation of the growth performance and carcass characteristics of lambs produced in Quebec. Canadian Journal of Animal Science, 80, 25-33.

Hammond, J., Jr., Mason, I. L., \& Robinson, T. J. (1971). Hammond's Farm Animals (4th ed.). London: Butler \& Taner, Ltd, 293 pp.

Jeremiah, L. E., Jones, S. D. M., Tong, A. K. W., Robertson, W. M., \& Gibson, L. L. (1997a). The influence of lamb chronological age, slaughter weight and gender on yield and cutability. Sheep \& Goat Research Journal, 13, 39-49.

Jeremiah, L. E., Jones, S. D. M., Tong, A. K. W., Robertson, W. M., \& Gibson, L. L. (1997b). The influence of lamb chronological age, slaughter weigth, and gender on carcass composition. Sheep \& Goat Research Journal, 13, 30-38.

Jury, K. E., Fourie, P. D., \& Kirton, A. H. (1977). Growth and development of sheep IV. Growth of the musculature. New Zealand Journal of Agricultural Research, 20, 115-121.
Kempster, A. J., Croston, D., Guy, D. R., \& Jones, D. W. (1987). Growth and carcass characteristics of crossbred lambs by ten sire breeds, compared at the same estimated carcass subcutaneous fat proportion. Animal Production, 44, 83-98.

Kirton, A. H., Bennett, G. L., Dobbie, J. L., Mercer, G. J. K., \& Duganzich, D. M. (1995). Effect of sire breed (Southdown, Suffolk), sex, and growth path on carcass composition of crossbred lambs. New Zealand Journal of Agricultural Research, 38, 105-114.

Kirton, A. H., Carter, A. H., Clarke, J. N., Sinclair, D. P., Mercer, G. J. K., \& Duganzich, D. M. (1995). A comparison between 15 ram breeds for export lamb production. 1. Liveweights, body componente, carcass measurements, and composition. New Zealand Journal of Agricultural Research, 38, 347-360.

Kirton, A. H., Carter, A. H., Clarke, J. N., Sinclair, D. P., Mercer, G. J. K., \& Duganzich, D. M. (1996). A comparison of 15 ram breeds for export lamb production 2. Proportions of export cute and carcass class. New Zealand Journal of Agricultural Research, 39, 333-340.

Kremer, R., Barbato, G., Castro, L., Rista, L., Rosés, L., Herrera, V., \& Neirotti, V. (2004). Effect of sire breed, year, sex and weight on carcass characteristics of lambs. Small Ruminant Research, 53, 117-124.

Prud'Hon, M. (1976). La croissance globale de l'agneau: ses caracteristiques et ses lois. In 2émes Journees de la Recherche Ovine et Caprine, Paris. ITOVIC. pp 6-26.

Santos-Silva, J., Mendes, I. A., \& Bessa, R. J. B. (2002). The effect of genotype, feeding system and slaughter weight on the quality of light lambs 1. Growth, carcass composition and meat quality. Livestock Production Science, 76, 17-25.

SAS (1998). SAS/STAT user's guide. Cary, NC: SASI, editar Inc..

Teixeira, A., Delfa, R., \& Treacher, T. (1996). Carcass composition and body fat depots of Galego Bragançano and crossbred lambs by Suffolk and Merino Precoce sire breeds. Animal Science, 63, 389-394.

Teixeira, A., Delfa, R., \& Alberti, P. (1998). Influence of production factors on the characteristics of meat from ruminants in Mediterranean area. In Proceedings of the international symposium on basis of the quality of typical Mediterranean animal products. EAAP. pp. 315-319.

Wolf, B. T., Smith, C., \& Sales, D. I. (1980). Growth and carcass composition in the crossbred progeny of six terminal sire breeds of sheep. Animal Production, 31, 307-313.

Wood, J. D., MacFie, H. J. H., Pomeroy, R. W., \& Twinn, D. J. (1980). Carcass composition in four sheep breeds: the importance of type of breed and stage of maturity. Animal Production, 30, 135-152.

Wood, J. D., MacFie, H. J. H., \& Brown, A. J. (1983). Effects of body weight, breed and sex on killing-out percentege and non-carcass component weights in lambs. Meat Science, 9, 89-99.

Wylie, A. R. G., Chestnutt, D. M. D., \& Kilpatrick, D. J. (1997). Growth and carcass characteristics of heavy slaughter weight lambs: effects of sire breed and sex of lamb and relationships to serum metabolites and IGF-1. Animal Science, 64, 309-318. 